\title{
FREQUENCY OF GENE ACE I POLYMORPHISM I-D IN ATHLETES OF DIFFERENT SPORTS
}

\author{
FREQUÊNCIA DO POLIMORFISMO I-D DO GENE ECA I EM ATLETAS DEDIFERENTES ESPORTES
}

Agnelo Weber de Oliveira Rocha'1,2,3 (ID (Physical Education Professional)

Whendel Mesquita do

Nascimento ${ }^{3}$ (D)

(Physical Education Professional)

Cintia Mara da Costa Oliveira ${ }^{3}$ (DD (Biologist)

José Moura Pereira Neto 4 (iD (Pharmacist)

Ozanildo Vilaça do Nascimento 5 (iD (Physical Education Professional) João Otacílio Libardoni dos Santos ${ }^{5}$ (DD (Physical Education Professional)

Éricles Paiva Viera ${ }^{5}$ ID

(Physical Education Professional) Henver Simionato Brunetta ${ }^{6}$ (ID) (Physical Education Professional) Isabel da Mota Pontes 3 (D) (Biologist)

Spartaco Astolfi Filho 3 (ID (Biologist)

1. Universidade Paulista (UNIP), Institute of Health Sciences, Manaus, AM, Brazil.

2. Universidade Federal do Amazonas (UFAM), Diagnostic Molecular Laboratory, Manaus, AM, Brazil.

3. Postgraduate Program in Biodiversity and Biotechnology of Brazil's Legal Amazon (PPGBionorte), Manaus, AM, Brazil. 4. Universidade Federal do Amazonas (UFAM), Faculty of Pharmaceutical Sciences, Manaus, AM, Brazil.

5. Universidade Federal do Amazonas (UFAM), College of Physical Education and Physiotherapy, Manaus, AM, Brazil. 6. Laboratory of Investigation into Chronic Diseases, Department of Physiological Sciences, Center of Biological Sciences, Universidade Federal de Santa Catarina (UFSC), Florianópolis, Brazil.

\section{Correspondence:}

Agnelo Weber de Oliveira Rocha Universidade Paulista (UNIP),

Av. Mário Ypiranga, 4390,

Parque 10 de Novembro, Manaus, AM, Brazil. 69050-030.

agnelo.rocha@docente.unip.br agneloweber18@gmail.com

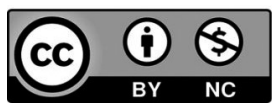

\begin{abstract}
Introduction: The angiotensin-converting enzyme I-D (ACE) polymorphism gene is one of the most widely investigated genetic variations in sports science. Apparently, allele I is related to endurance sports, while allele $D$ is related to power-strength activities. Nevertheless, studies have presented controversial results when it comes as to its occurrence in a variety of sports. Objective: This study aims to evaluate the frequency of gene ACE polymorphism I-D in professional athletes of collective or individual sports. Methods: Five $\mathrm{mL}$ blood were collected from 189 subjects divided into two groups: athletes (AG, $n=127$, wrestling, taekwondo, soccer, futsal and handball) and non-athletes (NAG, $\mathrm{n}=62$ ). The athletes group was subdivided by group modalities, into: collective and individual. Both groups were further subdivided into male and female. Thus, we have the groups $\mathrm{FAC}=$ collective female, $\mathrm{FAl}=$ individual female, $\mathrm{MAC}=$ collective male, and $\mathrm{MAl}=$ individual male. The statistical analysis was carried out by frequency test, and the Hardy-Weinberg equilibrium by the $x^{2}$ test. Results: The results for the $A G$ group indicated the following frequencies: $D D=7 \%, I D=44 \%$ and $\|=49 \%$. Allele frequency: $D=29 \%$ and $I=71 \%$. For the $N A G$, the results were: $D D=6.5 \%, I D=45.2 \%$ and $I I=48 \%$. Allele frequency: $D=29 \%$ and $l=71 \%$. The AG genotypic and allele frequencies did not differ statistically from those of the NAG $(p=0.982$ and $p=0.984$, respectively). However, we noticed that the genotypes II and ID frequencies were significantly higher than those of the DD. Conclusion: It can be concluded that the genotypic and allelic I-D frequencies of the ACE gene do not seem to influence performance in either group or individual sports. ACTN3 genotype frequencies did not vary significantly between male and female control subjects, and overall, there was no significant deviation from Hardy-Weinberg (H-W) equilibrium. Level of evidence I; Diagnostic studies-Investigating diagnostic test.
\end{abstract}

Keywords: Genetics; Sports; Angiotensin converting enzyme.

\section{RESUMO}

Introdução: O polimorfismo I-D do gene da enzima conversora da angiotensina (ECA) éuma das variações genéticas mais amplamente investigadas na ciência do esporte. Aparentemente, o alelo l está relacionado aos esportes de resistência e o alelo $D$ às atividades de força. Entretanto, os estudos têm apresentado resultados controversos quanto a sua ocorrência em diversos esportes. Objetivo: O presente estudo pretende avaliar a frequência do polimorfismo I-D do gene da ECA em atletas profissionais de esportes coletivos ou individuais. Métodos: Cinco $\mathrm{mL}$ de sangue foram coletados de 189 indivíduos divididos em dois grupos: atletas (GA, $n=127$, praticantes de luta livre, taekwondo, futebol, futsal ou handebol) e não atletas (GNA, n=62). O grupo de atletas foi subdividido de acordo com a modalidade: coletiva e individual. Ambos os grupos foram também subdivididos em masculino e feminino. Portanto, temos os grupos $F A C=$ feminino coletivo, $F A l=$ feminino individual, $M A C=$ masculino coletivo, $M A l=$ masculino individual . A análise estatística foi realizada através do teste de frequência e o equilibrio de Hardy-Weinberg pelo teste $x^{2}$. Resultados: Os resultados para o GA indicaram as seguintes frequências: $D D=7 \%, I D=44 \%$ e $\|=49 \%$. Frequência alélica: $D=29 \%$ e $=71 \%$. Para o GNA, os resultados foram: $D D=6,5 \%, I D=45,2 \%$ e $l=48 \%$. Frequência alélica: $D=29 \%$ e $=71 \%$. As frequências genotípicas e alélicas do GA não se diferiram estatisticamente daquelas do GNA ( $p=0,982$ e $p=0,984$, respectivamente). Entretanto, notamos que as frequências dos genótipos II e ID se apresentaram significativamente maiores do que aquelas do DD. Conclusão: Pode-se concluir que as frequências I-D genotípicas e alélicas do gene da ECA não pareceram influenciar o desempenho tanto nos esportes individuais como coletivos. As frequências do genótipo ACTN3 não variaram significativamente entre os indivíduos de controle de ambos os sexos, e, no geral, não houve um desvio significativo do equilíbrio de Hardy-Weinberg (H-W). Nível de evidência l; Estudos diagnósticos-Investigação de um exame para diagnóstico.

Descritores: Genética; Esportes; Enzima conversora de angiotensina.

\section{RESUMEN}

Introducción: El polimorfismo I-D del gen de la enzima convertidora de la angiotensina (ECA) es una de las variaciones genéticas más ampliamente investigadas en la ciencia del deporte. Aparentemente, el alelo l está relacionado a los deportes de resistencia y el alelo D a las actividades de fuerza. Entretanto, los estudios han presentado resultados controvertidos cuanto a su ocurrencia en diversos deportes. Objetivo: El presente estudio pretende evaluar la frecuencia del polimorfismo I-D del gen de la ECA en atletas profesionales de deportes colectivos o individuales. Métodos: Cinco 
$\mathrm{mL}$ de sangre fueron recolectados de 189 individuos divididos en dos grupos: atletas (GA, $n=127$ practicantes de lucha libre, taekwondo, fútbol, futsal y hándbol) y no atletas (GNA, n=62). El grupo de atletas fue subdividido de acuerdo con la modalidad: colectiva e individual. Ambos grupos fueron también subdivididos en masculino y femenino: Por lo tanto, tenemos los grupos $F A C=$ colectivo femenino, $F A l=$ femenino individual, $M A C=$ masculino colectivo, $M A l=$ masculino individual. El análisis estadístico fue realizado a través del test de frecuencia, y el equilibrio de Hardy-Weinberg por el test $x^{2}$. Resultados: $L o$ resultados de GA indicaran las siguientes frecuencias: $D D=7 \%, I D=44 \%$ y $\|=49 \%$. Frecuencia alélica: $D=29 \%$ e I $=71 \%$. Para el $G N A$, los resultados fueron: $D D=6,5 \%, I D=45,2 \%$ y $\|=48 \%$. Frecuencia alélica: $D=29 \%$ e $=71 \%$. Las frecuencias genotípicas y alélicas del GA no difirieron estadísticamente de las del GNA ( $p=0,982$ y $p=0,984$, respectivamente). Entretanto, notamos que las frecuencias de los genotipos II e ID se presentaron significativamente mayores que aquellas del DD. Conclusión: Se puede concluir que las frecuencias I-D genotípicas y alélicas del gen de la ECA no parecieron influenciar el desempeño tanto en los deportes individuales como colectivos. Las frecuencias del genotipo ACTN3 no variaron significativamente entre los individuos de control de ambos sexos $y$, en general, no hubo desvío significativo del equilibrio de Hardy-Weinberg (H-W). Nivel de evidencia I; Estudios diagnósticos-Investigación de un examen para diagnóstico.

Descriptores: Genética; Deportes; Enzima convertidora de angiotensina.

\section{INTRODUCTION}

Genetic polymorphisms have been frequently associated with athletic performance in different sports as it is likely that some genes influence phenotypes such as muscular strength-power or the endurance capacity. ${ }^{1}$ The ACE (angiotensin converting-enzyme) insertion-delection is one of the most studied polymorphisms in the last years as it is mainly related to the athletes aerobic capacity. 2,3 The ACE is an enzyme that integrates the aldosterone angiotensine renine system (AARS), which is fundamental to the arterial pressure regulation. ${ }^{4}$ Its main activity is the cleavage of two angiotensine aminoacid I (Ang I) residues, converting it into angiotensine II (Ang II), a potent vasoconstrictor that is connected to the angotensine receptor 1 (AT-1), thus promoting higher absorption of sodium and water in the renal tubules, ${ }^{5,6}$ However, some specific tissues such as the muscular and the adipose ones present AARS local activity. ${ }^{4}$

The ACE gene locus is $17 q 23$ and its alleles can present an insertion (I) or deletion (D) polymorphisms of 287 base pairs (bp) in the 16 intron, which can affect the organism hemodynamic capacity. ${ }^{7,8}$ Rigat et al. ${ }^{9}$ whose serum ACE levels were concomitantly measured. Allele frequencies were 0.6 for the shorter allele and 0.4 for the longer allele. A marked difference in serum ACE levels was observed between subjects in each of the three ACE genotype classes. Serum immunoreactive ACE concentrations were, respectively, 299.3 +/-49, 392.6+/-66.8, and 494.1 +/-88.3 micrograms/liter, for homozygotes with the longer allele $(n=14$ verified that homozygote subjects for the genotype II present lower ACE plasmatic concentration when compared to those carrying genotype DD. Moreover, these DD homozygotes seem to present higher risks to develop arterial hypertension. ${ }^{10}$

The information on the ACE influence in the performance is still controversial in the sports contexts. Zhang et al. ${ }^{11}$ verified that subjects carrying alleles II present higher proportion of fibers type I compared to DD genotype homozygote individuals, which presented higher number of type II fibers. Other studies have suggested that allele I can influence the performance of athletes of aerobic sports predominantly, whereas allele D would be related to events which strength-power is the most demanded physical capacity. 12-15 However, results involving athletes, both of endurance and strength-power, and control groups from different continents have presented different frequencies of ACE genotypes, 12,16,17 which generates controversy in literature.

After all the data presented, the aim of the present study was the evaluation of the ACE gene ID polymorphism frequency in professional athletes of various individual and team sports. The risen hypothesis was that there would be differences in terms of genotypic frequency and the alleles distribution among different sports.

\section{MATERIALS AND METHODS}

The procedures followed in this study were conducted ethically according to the principles of the World Medical Association, Declaration of Helsinki and ethical standards in sport and exercise science research. The Ethics Committee of the Federal University of Amazonas approved the study under the number CAAE: 49475214.0.0000.5020 and written informed consent was obtained from each participant.

This study was composed of 189 subjects of both genders (male, $n=121$ and female, $n=68$ ) divided into athletes groups ( $A G, n=127$ age range 23.84+- 5.03 years) and non-athletes group (NAG, $n=62$ and age range $23,58+-4,49$ years), physically active and healthy. The AG group was composed of: wrestling athletes $(n=8)$, taekwondo $(n=20)$, soccer $(n=31)$, futsal $(n=41)$ and handball $(n=27)$ that participated of competitions state, national or international in the last 3 years. (Table 1)

The athletes coaches were contacted to explain the purpose and methods of study. After the consent of athletes and coaches, were invited to attend the molecular diagnostic laboratory of the Federal University of Amazonas (UFAM), to blood collection and filling out a registration form containing questions about personal characteristics, modality practiced, training time and competitions practiced in the last 3 years. Posteriorly, the AG group was subdivided in athletes group collective and individuals, both groups were subdivided in FAC = collective female, $\mathrm{FAI}=$ individual female, $\mathrm{MAC}=$ collective male, $\mathrm{MAI}=$ individual male.

Blood samples ( $5 \mathrm{~mL}$ ) were collected in tubes containing EDTA. DNA extraction was performed using kit QIAamp ${ }^{\circledR}$ DNA Mini and Blood Mini Handbook QIAGEN. DNA was quantified by using Nanodrop ${ }^{\circledR}$ ND-1000 Thermo Scientific according to the manufacturers'instructions. Genotyping for the ACE gene variant was performed by polymerase chain reaction (PCR). The Primers used were 5'CTGGAGAGCCACTCCCATCCTTTCT3'

Table 1. Characterization of the experimental group by sports.

\begin{tabular}{c|c|c|c}
\hline Sports (n) & \multicolumn{2}{|c|}{ SEX } & Age (Mean $\pm \mathbf{d p}$ ) \\
\hline & $\begin{array}{c}\text { MALE } \\
\text { (n) }\end{array}$ & $\begin{array}{c}\text { FEMALE } \\
\text { (n) }\end{array}$ & \\
\hline Wrestling (8) & 6 & 2 & $25.60 \pm 7.09$ \\
\hline Taekwondo (20) & 17 & 3 & $21.55 \pm 5.80$ \\
\hline Soccer (31) & 18 & 13 & $21.22 \pm 4.13$ \\
\hline Futsal (41) & 14 & 27 & $21.82 \pm 3.24$ \\
\hline Handball (27) & 17 & 10 & $25.44 \pm 4.89$ \\
\hline Total (127) & 72 & 55 & $22.84 \pm 5.03$ \\
\hline
\end{tabular}


(forward), 5'GATGTGGCCATCACATTCGTCAGAT 3' (reverse primer). Allelic discrimination was performed by thermocycler (Mastercycler Gradient Personal Eppendorf ). Thermal cycle protocol involved was programmed to amplify under the following conditions: $95^{\circ} \mathrm{C}$ for 5 minutes; 35 cycles at $94^{\circ} \mathrm{C}$ for 30 seconds and $51^{\circ} \mathrm{C}$ for 30 seconds and $72^{\circ} \mathrm{C}$ for 60 seconds, with a final extension at $72^{\circ} \mathrm{C}$ for 5 minutes. Amplified products were electrophoresed on a $2 \%$ agarose gel. The agarose gel was subsequently stained with ethidium bromide and PCR products were displayed using an Eagle Eye II ultraviolet. The amplification can be visualized in Figure 1.

The ACE gene amplification may generate fragments with 491 or 191 pairs of bases (pb) in alleles I or D, respectively. Therefore, three different genotypes may appear: insertion homozygote II, heterozygote ID and deletion homozygote DD. It is relevant to highlight that during PCR preferential amplification of allele D over allele I may occur. ${ }^{18}$ Thus, in order to confirm the DD genotype a new PCR was carried out, making use of primers Forward: 5'-TGGGACCACAGCGCCCGCCACTAC - 3'and Reverse 5' - TCGCCAGCCCTCCCATGCCCATAA - 3', with similar conditions to the first PCR, except for the anelament temperature, which was $61^{\circ}$ in the confirmation and 5\% DMSO addition. ${ }^{19}$ The samples were applied in agarose gel $2 \%$, however, none of the samples presented alteration in the result.

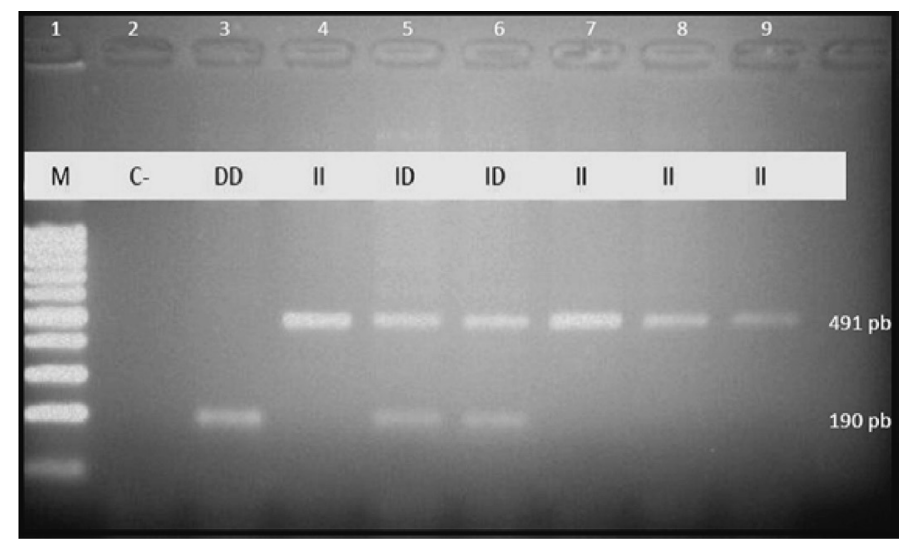

Figure 1. ECA gene I polymorphisms. "M" is the marker with 100pb and "c-" is the negative control. DD = homozygous deletion polymorphism (191pb); II = homozygous insertion polymorphism (490pb); ID = heterozygous polymorphism (191 and 490pb) if the count was performed at inferior and superior regions, respectively.

\section{Statistical analysis}

The statistical treatment was done according to the descriptive analysis. The genotypic and allelic frequencies were calculated using the statistics SPSS program (version 21.0). The Hardy-Weinberg equilibrium was measured by the tx 2 test. The genotypes percentages were determined through the cross reference tables, while the allelic frequencies proportions were done based on the $2 \times 2$ contingency tables.

\section{RESULTS}

The ACE genotypes frequency data of the total sample, as well as its stratificated form for the athlete group (AG) and the non-athlete group (NAG) is shown in Table 2 . The results indicate that there was no significant difference $(p=0.982)$ in the genotypic frequency between the groups AG and NAG. However, when the analysis was intragroup, a difference was observed ( $p=0.0001$ ) due to the low frequency of the DD genotype. The frequency of insertion or deletion alleles followed the same pattern, being insignificant between groups $(p=0.984)$, although different both inside the GE ( $p=0.0001)$ and in GNA ( $p=0,0001)$.

Figure 2 shows ACE genotypic frequency in the respective types of AG. There was difference $(p<0.05)$ in the genotypes proportions when the sports were grouped. Nevertheless, when each sport was accessed, the three genotypes did not differ in Taekwondo $(p=0.259)$.
Table 2. Genotype frequency and allelic frequency absolute and relative ACE gene in complete sample.

\begin{tabular}{c|c|c|c|c|c|c|c}
\hline \multirow{2}{*}{ Group } & \multicolumn{3}{|c|}{ ACE genotype n (\%) } & p & \multicolumn{2}{|c|}{$\begin{array}{c}\text { Allelic frequency } \\
\mathbf{n}(\%)\end{array}$} & P \\
\hline Athletes & DD & ID & II & & D & I & \\
\hline Non-athletes & $4(6,5 \%)^{\mathrm{a}}$ & $\begin{array}{c}56 \\
(44 \%)^{\mathrm{b}}\end{array}$ & $\begin{array}{c}28 \\
(49 \%)^{\mathrm{b}}\end{array}$ & 0.0001 & $\begin{array}{c}74 \\
(29 \%)^{\mathrm{c}}\end{array}$ & $\begin{array}{c}180 \\
(71 \%)^{\mathrm{d}}\end{array}$ & 0.0001 \\
\hline Total & $13(7 \%)^{\mathrm{a}, \mathrm{e}}$ & $\begin{array}{c}84 \\
(44 \%)^{\mathrm{b}, \mathrm{f}}\end{array}$ & $92(49 \%)^{\mathrm{b}, \mathrm{f}}$ & 0.0001 & $\begin{array}{c}36 \\
(29 \%\end{array}$ & $\begin{array}{c}88 \\
(71 \%)^{\mathrm{d}}\end{array}$ & 0.0001 \\
\hline
\end{tabular}

Chi square (athletes $a \neq b$ ) $=46.008, d f=2$ allelic frequency (athletes $c \neq d)=44,236, d f=1$. Chi square (non athletes $a \neq b)=22.387, d f=2$. Allelic frequency $($ non - athletes $c \neq d)=21.806, d f=1$. Chi square (athletes $x$ non athletes $\mathrm{a} \neq \mathrm{b})=22.387, \mathrm{df}=2$. Allelic frequency $($ non - athletes $c \neq d)=21.806, \mathrm{df}=1$. Chi square (athletes $x$ non
- athletes $\mathrm{a}=\mathrm{e} ; \mathrm{b}=\mathrm{f})=0.037, \mathrm{df}=2, \mathrm{P}=0.982$. Allelic frequency (athletes $x$ non - athletes $\mathrm{c}=\mathrm{g} ; \mathrm{d}=\mathrm{h})=0.000, \mathrm{df}$ $=1, p=0.984$. Chi square (total $\mathrm{e} \neq \mathrm{f})=68.376, \mathrm{df}=2$. Allelic frequency (total $\mathrm{g} \neq \mathrm{h}$ ) $140.577, \mathrm{df}=1 . \mathrm{DD}=$ deletion homozygote, ID = heterozygote, $\|$ = insertion homozygote.

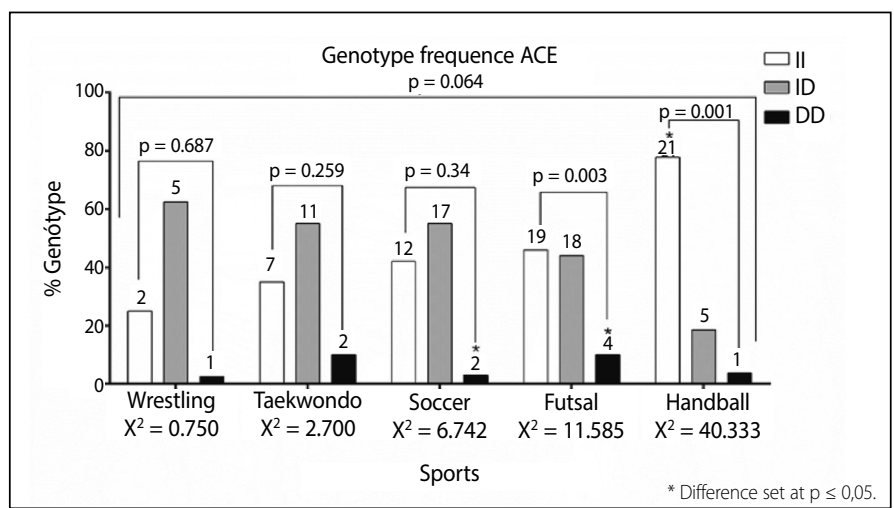

Figure 2. ACE genotypes frequencies of all modalities. The comparisons were conducted within each sports and with combined sports. The numbers above the columns represents the $\mathrm{n}$. $\|=$ insertion homozygous, $I D=$ heterozygous and $\mathrm{DD}=$ deletion homozygous. Total X2 $=14.745$.

The samples were also separated by individual and collective characteristics. The genotypic and allelic frequencies are shown in Figures $3 \mathrm{a}$ and $3 \mathrm{~b}$. The grouping of the two did not present differences among genotypes II, ID and DD ( $p=0.129)$. Similar result was verified in the genotypic frequency of individual sports $(p=0.208)$, however for team sports genotypes II, ID and DD were significantly different $(p=0.0001)$. The allelic frequencies were different among individual sports $(I>D$, $p=0,0001)$ and team sports $(I=D, p=0,102)$. In total, the frequency of allele I was higher than the allele $D(p=0,0001)$.

Figures $4 a$ and $4 b$ show data of ACE genotypic and allelic frequencies from groups separated by gender and aerobic or anaerobic sports. There was no difference in the genotypes of sports when grouped $(p=0,323)$, however, there was important difference $(p=0,0001)$ in collective and individual female groups, as well as in collective male groups. The only frequency that showed no difference was the individual male sports $(p=0,108)$.

The allelic frequency of the grouped sample was not significantly different $(p=0,140)$. However, when divided by gender and sport (individual and collective) the allele I frequency in the sample was significantly higher than $D(p=0,0001)$. Nevertheless, the alleles did not show difference $(p=0,527)$ for the female individual group.

\section{DISCUSSION}

The present study had the objective of analyzing the genotypic and allelic frequencies of professional athletes in various sports. The results of the study showed there was no significant difference among genotypes frequencies, as well as the allelic frequencies when AG and NAG were compared. However, genotype DD and the allele D were less frequent among the groups.

Some studies with similar lineation have shown no difference of genotypic and allelic frequencies among athletes and non-athletes, 


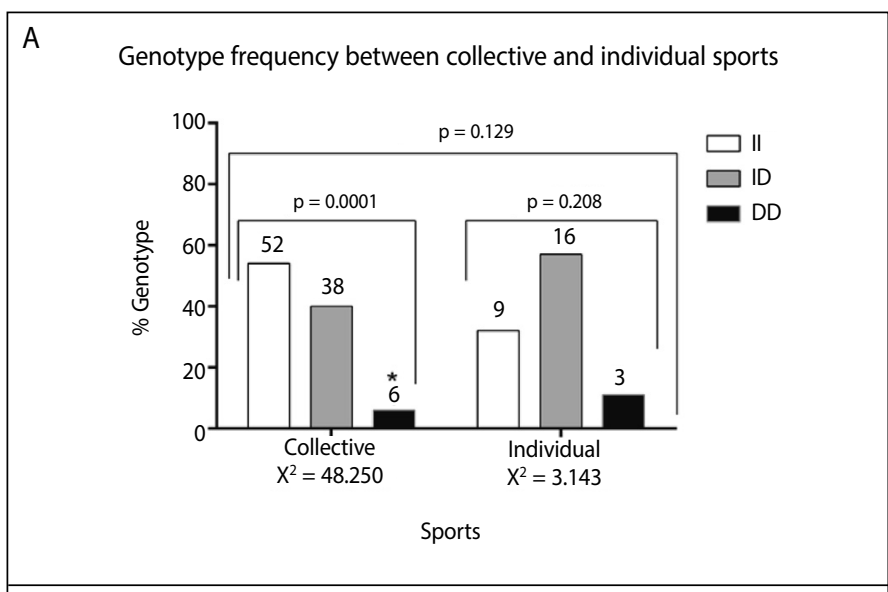

B

Allelic frequency between collective and individual sports

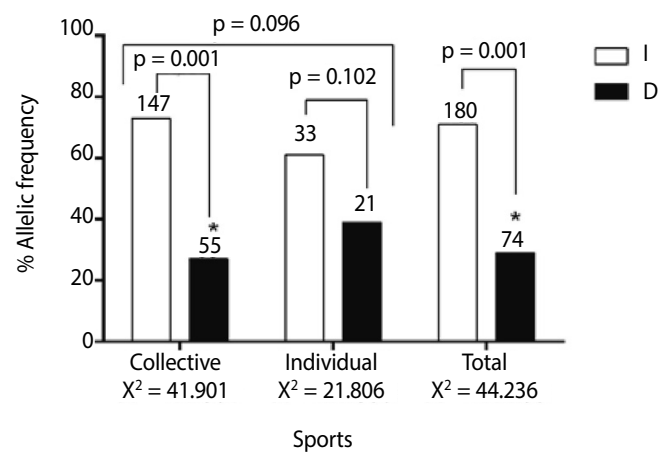

* Difference set at $p \leq 0,05$.

Figure 3. A) ACE genotypes frequencies. Comparisons between groups (no statistics difference $p=0.129$ ) and within groups (collective sports, $p=0.0001$ and individual sports, $p=0.208$ ). The numbers above the columns represents the $n . \|=$ insertion homozygous, $\mathrm{ID}=$ heterozygous and $\mathrm{DD}=$ deletion homozygous. B) ACE allelic frequencies within athletes of collectives and individual sports. $X^{2}$ collective sports $=41.901, X^{2}$ individual sports $=2.667$ and total. $X^{2}$ total $=44.236$. The numbers above the columns represents the $\mathrm{n} . \mathrm{I}=$ insertion allele and $\mathrm{D}=$ deletion allele.

while other investigations have identified important differences in the athletes and non-athletes groups. Costa et al..$^{20}$ and most of the published data refers to an I/D polymorphism leading to the presence (I allele did not find differences among ACE genotypes when swimmers were compared to non-athletes. Likewise Gunel et al. ${ }^{21}$ and functional ACE I/D and ACTN3 R577X polymorphisms have been associated with sprinter performance. The aim of this study was to determine the effect of these polymorphisms on sport performance among 37 elite athletes and 37 healthy controls. The ACE II genotype was identified in $32.43 \%$ of the control group and $8.11 \%$ of elite athletes, the DD genotype in $37.84 \%$ of the control group and $51.35 \%$ of the elite athletes, and the ID genotype in $29.73 \%$ of the control group and $40.54 \%$ of the elite athletes. With regard to the ACTN3 gene, the XX genotype, which confers an advantage for endurance activities, was identified in $10.81 \%$ of the control group and $35.14 \%$ of the elite athletes. The XX genotype was observed more frequently than the RR genotype (advantageous for sprinting did not find statistic differences in the frequency of polymorphism I-D of ACE when 37 elite athletes was compared to 37 healthy non-athlete subjects. On the other hand, Ginevičiene et al.'the angiotensin-converting enzyme (ACE observed difference $(p=0,025)$ between Lithuanian athletes and non-athletes of that country. Corroborating with Grenda et al. ${ }^{14}$ the purpose of the present study was to determine the interaction between both ACE ID and ACTN3 R577X polymorphisms and sprint and endurance performance in swimmers. Genomic DNA was extracted from oral epithelial cells using GenElute Mammalian Genomic DNA
A

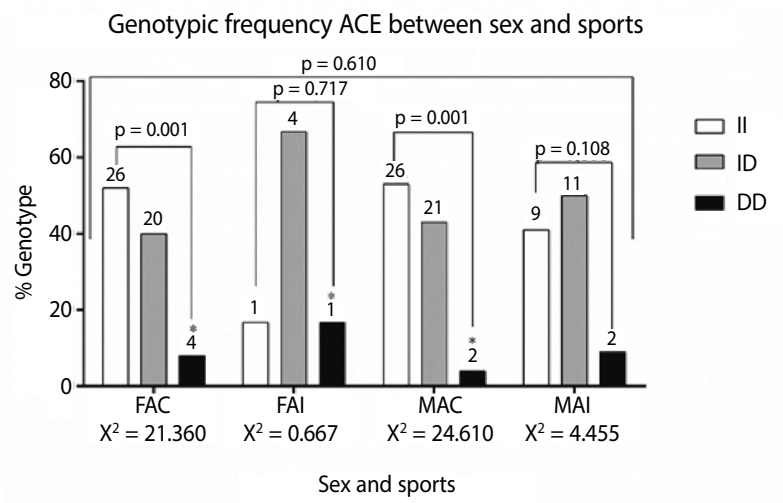

B

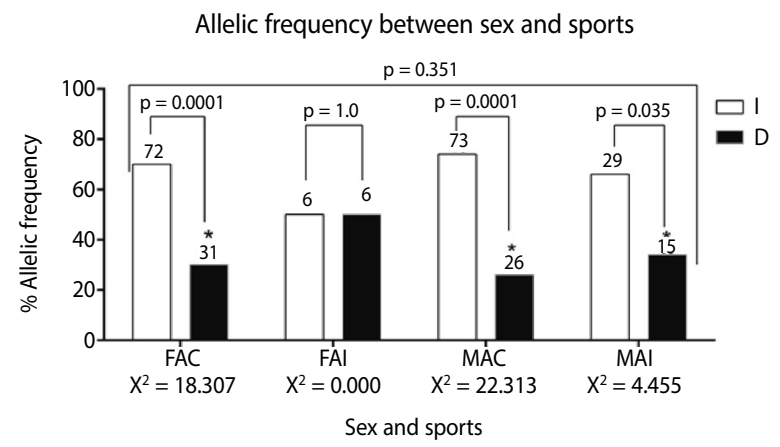

* Difference set at $p \leq 0,05$.

Figure 3. A) ACE genotypes frequencies between sexy and sports. FAC = collective fema$\mid \mathrm{e} ; \mathrm{FAl}=$ individual female; $\mathrm{MAC}=$ collective male; $\mathrm{MAl}=$ individual male. The numbers above the bars represents the $n$. $\|=$ insertion homozygous, ID = heterozygous and DD $=$ deletion homozygous. Total $X 2=4.496$. B) ACE genotypes frequencies between sexy and sports. $\mathrm{FAC}=$ collective female; $\mathrm{FAl}=$ individual female; $\mathrm{MAC}=$ collective male; $\mathrm{MA}$ $=$ individual male. The numbers above the bars represents the $\mathrm{n} . \mathrm{I}=$ insertion allele and $\mathrm{D}=$ deletion allele. Total $\mathrm{X} 2=4.496$.

Miniprep Kit (Sigma, Germany that identified, both in the swimmers and its stratification in short or long distance competitors, difference when compared to the non-athlete.

Researches involving athletes, ${ }^{15,22}$ elderly ${ }^{23}$ or children and adolescents ${ }^{8}$ showed different frequencies when compared to this study. It t is important to highlight that any of the investigations aforementioned were carried out in the Northern region of Brazil, site of the present study. Coelho et al. ${ }^{22}$ verified the following frequencies in soccer players of different categories from Southeast region in Brazil: DD (29,42\%), ID (51,42\%) e II $(19,14 \%)$, then, the genotypes did not present difference $(P=0,85)$. Bordoni et al. ${ }^{8}$ have tested the association between ACE I-D polymorphism, corporal composition and hydration state in 306 Italian young and verified frequencies DD (41\%), ID (44\%) and II (15\%). The data shows an inversely proportional relationship between frequencies of genotypes DD and II when compared to the frequencies of the present study.

It has been suggested that allele I presents distinctive relationship with sports which the endurance capacity is preponderant. 24,25 Montgomery et al. ${ }^{24}$ related the genotypic and allelic frequency of ACE I-D polymorphism into two groups. The first one was made of 25 mountaineers who competed climbing to heights above 7000 meters, while the second one was made of 123 military from the UK DD. Both were subjected to exercises to assess the upper limbs muscular stamina. Results showed that the mountaineers who achieved longer distances (above 8000 meters) were homozygotes $\|(n=6)$ or heterozygotes $(n=9)$. As for the military, genotypes homozygotes II did the exercise 
for 79,4 +- 25,2 seconds, heterozygotes ID for $24.7+-8,8$ seconds and homozygotes DD $7.1+-14,9(p=0,001)$.

Grenda et al. ${ }^{14}$ the purpose of the present study was to determine the interaction between both ACE ID and ACTN3 R577X polymorphisms and sprint and endurance performance in swimmers. Genomic DNA was extracted from oral epithelial cells using GenElute Mammalian Genomic DNA Miniprep Kit (Sigma, Germany verified that in 49 Polish long-distance elite swimmers the frequency of genotype DD was under $10 \%$, whereas, in 147 sprinters that frequency rose to 26,7\%. Even though these results have confirmed the hypothesis that the allele I may be related to better performance at endurance events, other findings present results that disagree with such hypothesis. ${ }^{12,26} \mathrm{Amir}$ et al. ${ }^{12}$ the I allele promotes more power-orientated events. We tested this hypothesis by determining the frequency of ACE ID alleles amongst 121 Israeli top-level athletes classified by their sporting discipline (marathon runners or sprinters verified higher proportion of genotype DD (62\%) in comparison to genotypes ID (29\%) and II (9\%) in Israeli elite marathonists. Another study with endurance elite athletes carried out by Grealy et al. ${ }^{26}$ diagnosed, in 196 Ironman contestants, $42,3 \%$ of genotypes $\mathrm{DD}, 46,9 \% \mathrm{ID}$ and $10,7 \% \mathrm{II}$, corroborating Amir etal. ${ }^{12}$ the I allele promotes more power-orientated events. We tested this hypothesis by determining the frequency of ACE ID alleles amongst 121 Israeli top-level athletes classified by their sporting discipline (marathon runners or sprinters results.

On the other hand, other investigations indicate that allele D frequency is higher in sports that demand higher muscle strength-power. ${ }^{27,28}$ Nevertheless, when Heffernan et al..$^{29}$ evaluated the frequency in 505 Rugby players did not find significant genotypic differences ( $D D=$ $21,4 \%, I D=49,7 \%$ e $\|=28,9 \%)$. Opposing these results, Costa et al. ${ }^{20}$ and most of the published data refers to an I/D polymorphism leading to the presence ( $I$ allele evaluated the frequency of 39 Portuguese elite swimmers ( 25 of up to $200 \mathrm{~m}$ racers and other 14 of races ranging from 400 to $1500 \mathrm{~m}$ ). The genotypic frequencies of the short-distance swimmers were DD 56\% and ID 44\%, while for mid-distance athletes the frequencies were DD (43\%), ID (21\%) and II (36\%). These results indicate an increased presence of allele $D$ in short-distance races athletes, however, the more distant the race, the more evident is the frequency of allele I. The same authors evaluated 58 high-performance athletes (35 swimmers and 23 triathletes), grouping them into long or mid-distance types. Genotype II was not find in the short-distance group, while there was no important difference found in the middistance group, Costa et al..$^{30}$ This data corroborates Papadimitriou et al. ${ }^{28}$ who verified better results in Olympic-level sprinters carriers of allele D. Likewise, Massidda et al. ${ }^{31}$ even if this association has been often conflicting. The aim of the present study was to investigate the association between the ACE and the ACTN3 genotypes and elite performance in Italian male athletes. The ACTN-3 R577X and the ACE I/D genotype distributions of 59 elite male Italian athletes practicing gymnastics ( $G ; n=17$ did not find a genotype II carrier in a group of 12 sprinters. Moreover, the frequency of genotype DD was above $50 \%$ in gymnasts and soccer players.
Once this investigation assessed predominantly anaerobic sports, it was reasonable to expect that allele D would present frequency of at least $50 \%$. Instead, it was shown that in collective sports, $73 \%$ of allele I and $23 \%$ of allele $D(P=0.001)$, while in individual sports, the proportion was $39 \%$ of allele $I$ and $61 \%$ of allele $(P=0.102)$. Although the results found in individual sports are similar to other studies, ${ }^{12,25,28}$ when the groups were united, the total frequency was $71 \%$ I and 29\% D. Therefore, the sample allelic frequency of this study differed significantly from those found in studies aforementioned.

Wang et al. ${ }^{25}$ compared the genotypic frequencies of American and European short and mid-distance swimmers ( $\leq 400$ meters, $n=130$ ) and long-distance ( $>400$ meters, $n=70$ ) against Asian sprint swimmers ( $\leq 100$ meters, $n=166)$ and mid-distance ones (200-400 meters, $n=160$ ). Caucasian sprint and mid-distance swimmers showed higher frequencies of genotypes DD $(40,7 \%)$ and ID $(39,8 \%)$ in comparison to II $(19,5 \%)$. However, long-distance contestants showed similar genotypic frequencies between II 24,2\% e DD 28,8\%. Among Asians, frequencies corroborate the results of the present study. Short-distance athletes presented the following percentage, DD 9,6\%, ID 34,9\% and II 55,4\%, while for mid-distance, genotypes DD, ID and II presented frequencies 7,5\%,49,4\% and 43,1\%, respectively. Ginevičiene et al., ${ }^{32}$ the angiotensin-converting enzyme (ACE also identified correlation between allele I and anaerobic sports.

Apparently, the frequencies found in the present study are similar to the ones found in studies with Asian populations. 10,33,34 Park et al..$^{10}$ and to determine the association between ACE genotype and cardiovascular risk. Forty hypertensive adolescents (16-17 years old, systolic blood pressure (BP found higher frequencies of genotypes ID and II than genotype DD in young Koreans. Meanwhile, Chiu et al. ${ }^{33}$ verified frequencies of DD (7\%), ID (44\%) and II (49\%) in young female Asian athletes. Malhotra et al..$^{34}$ a sub-mountainous population of the Himalayan region, are known for strength and bravery. In the present study when lu201cGorkhalu201d is used without brackets, we are mentioning Gorkhas of Tibeto-Burman origin. Physical capability, strength and endurance are important components of fitness associated with genetic traits. The aim of this study was to examine the endurance potential of male Gorkha soldiers, based on endurance-related genetic markers ACE I/D, ACTN3 Arg (R identified frequencies DD (10\%), ID (47\%) and II (43\%) in 374 Asian military from sub-mountainous regions. In this way, two points could be made: 1) The I-D polymorphism frequency of the ACE is presented in different ways in different populations and, 2) allele $D$ is not always related to strength-power events nor is allele I linked to endurance events.

\section{CONCLUSION}

The present study evinces that genotypic and allelic frequencies of gene ECAI did not differ between athletes and non athletes. In addition, in the athletes group of collective sports it was observed higher frequency of the homozygous insertion genotype.

All authors declare no potential conflict of interest related to this article

AUTHORS' CONTRIBUTIONS: Each author made significant individual contributions to this manuscript. AWOR: writing, revision, collection of samples, molecular analyses, statistical treatment, intellectual concept and preparation of the entire research project; WMN: molecular analyses, data analysis and writing; CMCO: molecular analyses and revision; OVN: molecular analyses and writing; JPMN: molecular analyses and writing; JOLS: writing and revision; EPV: collection of samples and writing; HSB: writing and revision; IMP: collection of the samples, molecular analyses and writing; SAF (0000-0001-7246-6350* : writing and revision. All the authors revised and approved the final version of the manuscript.

\section{REFERENCES}

1. Ahmetov II, Fedotovskaya ON. Current progress in sports genomics. Adv Clin Chem. Elsevier; 2015;70:247-314

2. Ginevičienè V, Pranculis A, Jakaitienè A, Milašius K, Kučinskas V. Genetic variation of the human ACE and ACTN3 genes and their association with functional muscle properties in Lithuanian elite athletes. Medicina (Kaunas). 2011;47(5):284-90.
3. Ma F, Yang Y, Li X, Zhou F, Gao C, Li M, et al. The association of sport performance with ACE and ACTN3 genetic polymorphisms: a systematic review and meta-analysis. PLoS One. 2013;8(1):e54685.

4. Lemes VAF, Neves AL, Guazzelli IC, Frazzatto E, Nicolau C, Corrêa-Giannella ML, et al. Angiotensin converting enzyme insertion/deletion polymorphism is associated with increased adiposity and blood pressure in obese children and adolescents. Gene. 2013;532(2):197-202. 
5. Bosnyák E, Trájer E, Udvardy A, Komka Z, Protzner A, Kováts T, et al. ACE and ACTN3 genes polymorphisms among female Hungarian athletes in the aspect of sport disciplines. Acta Physiol Hung. 2015;102(4):451-8

6. van Ginkel S, Ruoss S, Valdivieso P, Degens $\mathrm{H}$, Waldron S, de Haan A, et al. ACE inhibition modifies exercise-induced pro-angiogenic and mitochondrial gene transcript expression. Scand J Med Sci Sports. 2016;26(10):1180-7.

7. Freitas SR, Cabello PH, Moura-Neto RS, Dolinsky LC, Bóia MN. Combined analysis of genetic and environmental factors on essential hypertension in a Brazilian rural population in the Amazon region. Arq Bras Cardiol. 2007;88(4):447-51.

8. Bordoni L, Napolioni V, Marchegiani F, Amadio E, Gabbianelli R. Angiotensin-Converting Enzyme Ins/ Del Polymorphism and Body Composition:The Intermediary Role of Hydration Status. J Nutrigenet Nutrigenomics. 2017;10(1-2):1-8.

9. Rigat B, Hubert C, Alhenc-Gelas F, Cambien F, Corvol P, Soubrier F. An insertion/deletion polymorphism in the angiotensin l-converting enzyme gene accounting for half the variance of serum enzyme levels. J Clin Invest. 1990;86(4):1343-6.

10. Park EY, Ahn H-M, Lee JA, Hong YM. Insertion/deletion polymorphism of angiotensin converting enzyme gene in Korean hypertensive adolescents. Heart Vessels. 2009;24(3):193-8.

11. Zhang B, Tanaka H, Shono N, Miura S, Kiyonaga A, Shindo M, et al. The I allele of the angiotensin-converting enzyme gene is associated with an increased percentage of slow-twitch type I fibers in human skeletal muscle. Clin Genet. 2003;63(2):139-44.

12. Amir O, Amir R, Yamin C, Attias E, Eynon N, Sagiv M, et al. The ACE deletion allele is associated with Israeli elite endurance athletes. Exp Physiol. 2007;92(5):881-6.

13. Min SK, Takahashi K, Ishigami H, Hiranuma K, Mizuno M, Ishii T, et al. Is there a gender difference between ACE gene and race distance? Appl Physiol Nutr Metab. 2009;34(5):926-32.

14. Grenda A, Leońska-Duniec A, Kaczmarczyk M, Ficek K, Król P, Cięszczyk P, et al. Interaction between ACE I/D and ACTN3 R557X polymorphisms in polish competitive swimmers. J Hum Kinet. 2014;42:127-36.

15. Gunel T, Gumusoglu E, Hosseini MK, Yilmazyildirim E, Dolekcap I, Aydinli K. Effect of angiotensin I-converting enzyme and a-actinin-3 gene polymorphisms on sport performance. Mol Med Rep. 2014;9(4):1422-6.

16. Xi B, Ruiter R, Chen J, Pan H, Wang Y, Mi J. The ACE insertion/deletion polymorphism and its association with metabolic syndrome. Metabolism. 2012;61(6):891-7.

17. Mägi A, Unt E, Prans $E$, Raus $L$, Eha J, Veraksitš $A$, et al. The association analysis between $A C E$ and ACTN3 genes polymorphisms and endurance capacity in young cross-country skiers: longitudinal study. J Sports Sci Med. 2016;15(2):287-94.

18. aber-Ayad MM, Nassar YS, Latif IA. Angiotensin-converting enzyme I/D gene polymorphism affects early cardiac response to professional training in young footballers. J Renin Angiotensin Aldosterone Syst. 2014;15(3):236-42.

19. Shanmugam V, Sell KW, Saha BK. Mistyping ACE heterozygotes. PCR Methods Appl. 1993;3(2):120-1.
20. Costa AM, Silva AJ, Garrido ND, Louro H, de Oliveira RJ, Breitenfeld L. Association between ACE D allele and elite short distance swimming. Eur J Appl Physiol. 2009;106(6):785-90

21. Gunel T, Gumusoglu E, Hosseini MK, Yilmazyildirim E, Dolekcap I, Aydinli K. Effect of angiotensin I-converting enzyme and a-actinin-3 gene polymorphisms on sport performance. Mol Med Rep. 2014;9(4):1422-6.

22. Coelho DB, Pimenta E, Rosse IC, Veneroso C, Pussieldi G, Becker LK, et al. Angiotensin-converting enzyme (ACE-I/D) polymorphism frequency in Brazilian soccer players. Appl Physiol Nutr Metab. 2016;41(6):692-4.

23. Garatachea N, Fiuza-Luces C, Torres-Luque G, Yvert T, Santiago C, Gómez-Gallego F, et al. Single and combined influence of ACE and ACTN3 genotypes on muscle phenotypes in octogenarians. Eur J App Physiol. 2012;112(7):2409-20.

24. Montgomery HE, Marshall R, Hemingway H, Myerson S, Clarkson P, Dollery C, et al. Human gene for physical performance. Nature. 1998;393(6682):221-2.

25. Wang G, Mikami E, Chiu LL, de Perini A, Deason M, Fuku N, et al. Association analysis of ACE and ACTN3 in elite Caucasian and East Asian swimmers. Med Sci Sports Exerc. 2013;45(5):892-900.

26. Grealy R, Herruer J, Smith CL, Hiller D, Haseler LJ, Griffiths LR. Evaluation of a 7-gene genetic profile for athletic endurance phenotype in ironman championship triathletes. PLoS One. 2015;10(12):e0145171.

27. Pereira A, Costa AM, Izquierdo M, Silva AJ, Bastos E, Marques MC. ACE I/D and ACTN3 R/X polymorphisms as potential factors in modulating exercise-related phenotypes in older women in response to a muscle power training stimuli. Age (Dordr). 2013;35(5):1949-59

28. Papadimitriou ID, Lucia A, Pitsiladis YP, Pushkarev VP, Dyatlov DA, Orekhov EF, et al. ACTN3 R577X and ACE I/D gene variants influence performance in elite sprinters: a multi-cohort study. BMC Genomics. 2016;17:285.

29. Heffernan SM, Kilduff LP, Erskine RM, Day SH, McPhee JS, McMahon GE, et al. Association of ACTN3 R577X but not ACE I/D gene variants with elite rugby union player status and playing position Physiol Genomics. 2016;48(3):196-201.

30. Costa AM, Silva AJ, Garrido N, Louro H, Marinho DA, Marques MC, et al. Angiotensin-converting enzyme genotype affects skeletal muscle strength in elite athletes. J Sports Sci Med. 2009:8(3):410-8.

31. Massidda M, Corrias L, Scorcu M, Vona G, Calò MC. ACTN-3 and ACE genotypes in elite male Italian athletes. Anthropol Rev. 2012;75(1):51-9.

32. Ginevičienè V, Pranculis A, Jakaitienè A, Milašius K, Kučinskas V. Genetic variation of the human ACE and ACTN3 genes and their association with functional muscle properties in Lithuanian elite athletes. Medicina (Kaunas). 2011;47(5):284-90.

33. Chiu LL, Chen TW, Hsieh SS, Hsieh LL. ACE I/D, ACTN3 R577X, PPARD T294C and PPARGC1A Gly482Ser polymorphisms and physical fitness in Taiwanese late adolescent girls. J Physiol Sci. 2012;62(2):115-21.

34. Malhotra S, Preet K, Tomar A, Rawat S, Singh S, Singh I, et al. Polygenic study of endurance-associated genetic markers ACE I/D, ACTN3 Arg (R) 577Ter (X), CKMM A/G Ncol and eNOS Glu (G) 298Asp(T) in male Gorkha soldiers. Sport Med Open. 2017;3(1):17 